\section{pH, Presents a New Weapon in the Battle Against COVID-19}

\author{
Keywords \\ COVID-19; Saliva; SARS-CoV-2; $\mathrm{pH}$
}

\section{Introduction}

As of March 2020, according to the report from recent news, an estimated more than 1.7 billion people around the world had been ordered to "Stay-at-Home" or affected by country lockdown because of COVID-19 [1]. People are living in the lockdown scenario continuously exposed to the unknown condition of the virus. We need to supply Personal Protective Equipment (PPE) and disinfectant materials such as detergents, alcohol and surfactants to individuals as quickly as possible. However, with the current rapid spreading rate of COVID-19 globally, PPEs, disinfectants, and related protocols are challenging to arrive in time. Besides the cleanse of the coronavirus on rough surfaces and human skin, sometimes we need to remove the potential coronavirus resided on the delicate surface of items such as fresh-produces and foods. For the 1.7 billion population in lockdown, it is vital to provide fresh and active food without any concern while keeping the waste materials at minimum is essential at this critical time. Lack of essential nutrients, vitamins, and trace elements make the immune system weaken and suspect more human beings against COVID-19 [2].

Information from the structure of COVID-19 pointed out that this specific virus, SARS-CoV-2, contains a lipid envelope, which keeps this coronavirus invincible [3]. The entry mechanism of SARSCoV-2 in COVID-19 uses S-1 spike proteins to attach to numerous ACE receptors in the human respiratory tract. ACE-2 receptors on the human lungs are the primary docking site for COVID-19's S-1 spike protein to attach [3]. In recent study on the virus structure of COVID-19, which SARS-CoV-2 belongs to the beta coronavirus subtype [4]. The virus has a round outer lipid bilayer membrane that has a diameter of approximately 60-140 nm [4]. Like other coronaviruses, SARS-CoV-2's lipid bilayer membrane is sensitive to UV and heat treatments. Furthermore, the SARS-CoV-2 virus in COVID-19 can be inactivated effectively by lipid solvents such as ether (75\%) solution, ethanol, chlorine disinfectant, peroxyacetic acid, and some chloroform [4].

Applying the method to sterilization, such as the use of detergent, surfactant, UV, and heat can deteriorate precious produces, food, and other delicate materials. Instead, we need to find alternative methods to remove SARS-CoV-2 from the delicate surfaces. Listed studies and reviews have pointed out how an alteration in $\mathrm{pH}$ level can affect virus activities in human body (Table 1). The extreme acidic or basic environment can potentially inhibit the virus's function on stability and transmission. In the study human coronavirus $229 \mathrm{E}$ was diluted 10 -fold in buffers at different $\mathrm{pH}$ levels and incubated for 6 hours [5].

\section{Sournal of Oral Biology}

\author{
Mohammad Ali Saghiri ${ }^{1,2^{*}}$ and Chun Kai Tang ${ }^{3}$ \\ ${ }^{I}$ Director of Biomaterial and Prosthodontic Laboratory, Department \\ of Restorative Dentistry, NJ \\ ${ }^{2}$ Department of Endodontics, University of the Pacific, USA \\ ${ }^{3}$ Master Student, Rutgers Biomedical and Health Sciences, NJ
}

*Address for Correspondence: Mohammad Ali Saghiri, Director of Biomaterial and Prosthodontic Laboratory \& Assistant Professor, Department of Restorative Dentistry, Rutgers School of Dental Medicine, NJ; Department of Endodontics, University of the Pacific, Arthur A. Dugoni School of Dentistry, San Francisco, California, MSB C639A-Rutgers Biomedical and Health Sciences, 185 South Orange Avenue, Newark, NJ 07103, USA, P. 973-972-7925 F. 973972-0370; E-mail: Mohammadali.saghiri@rutgers.edu

Submission: 22-May-2020

Accepted: $18-J u l y-2020$

Published: 21-July-2020

Copyright: (c) 2020 M A Saghiri. This is an open access article distributed under the Creative Commons Attribution License, which permits unrestricted use, distribution, and reproduction in any medium, provided the original work is properly cited.

They found out that the optimal stability of the virus was at $\mathrm{pH} 6$, at both $4{ }^{\circ} \mathrm{C}$ and $33^{\circ} \mathrm{C}$. However, when the virus is at extreme $\mathrm{pH}$ levels, it was more stable when incubated at $4{ }^{\circ} \mathrm{C}$. When they exposed the virus in $\mathrm{pH} 4$ or $\mathrm{pH} 9$ at $33^{\circ} \mathrm{C}$, viral infectivity was not detectable. Another investigation discovered that this coronavirus was inactivated by the use Ultraviolet Light (UV), use of heat treatment $65^{\circ} \mathrm{C}$ or higher, place the virus in alkaline $(\mathrm{pH}>12)$ or acidic $(\mathrm{pH}<3)$ conditions, also treat the virus with formalin and glutaraldehyde [6]. A study indicated that the survival rate of coronavirus SARS COV-1 to host cells was affected by low $\mathrm{pH}$ levels and warm temperatures $[7,8]$. The activity of coronavirus decreases when the $\mathrm{pH}$ is lower than neutral $(\mathrm{pH}<7.0)$ and when the temperature increase from $20^{\circ} \mathrm{C}$ to 37 ${ }^{\circ} \mathrm{C}$ [7]. This study can be useful when dealing with COVID-19 since the stability and functionalities are similar to SARS-CoV-1 (Figure 1).

In our daily life, a wide range of acidic fluids with different $\mathrm{pH}$ levels ranging from $\mathrm{pH} 2.0 \sim \mathrm{pH} 5.0$ was available to buy and use. Orange or grapefruit juice $(\mathrm{pH}=3.0)$, acetic acid/lemon juice $(\mathrm{pH}=2.0)$, citric acid/vinegar $(\mathrm{pH}=2.0)$, and Coke and Pepsi $(\mathrm{pH}=2.5)$ [9]. These acidic fluids are cheap, affordable, easier to obtain by normal civilians. According to a study on HIV prevention and treatment by using lemon juice and lime juice, Short et al. pointed out that when acidic solution mixed with human serums, the combined $\mathrm{pH}$ level

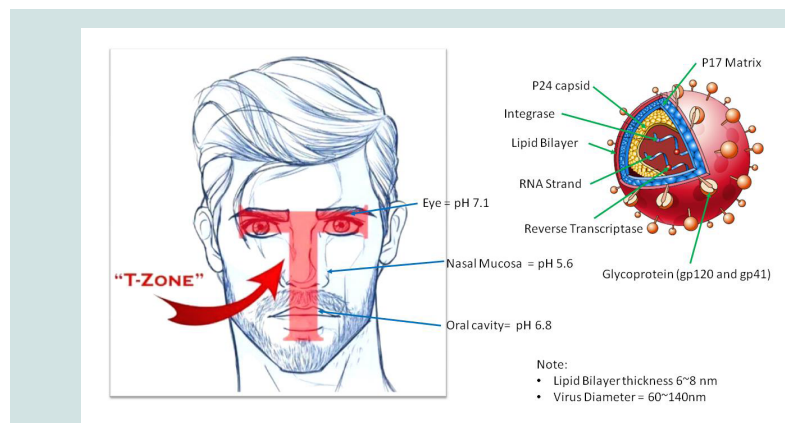

Figure 1: 
Table 1: Literatures and studies describing the relationship between viral infection and $\mathrm{pH}$ level.

\begin{tabular}{|c|c|c|c|c|c|}
\hline Title & Type of Article & Type of Virus Studied & $\begin{array}{l}\text { pH Level } \\
\text { Observed }\end{array}$ & Temperature & $\begin{array}{l}\text { Relationship found on viral } \\
\text { infection and changes in } \\
\text { pH level }\end{array}$ \\
\hline $\begin{array}{l}\text { Effect of } \mathrm{pH} \text { and temperature } \\
\text { on the infectivity of human } \\
\text { coronavirus } 229 \mathrm{E} \\
\text { Lamarre A. et al. [5] }\end{array}$ & Case Study & $\begin{array}{c}\text { Human coronavirus } \\
\text { 229E } \\
\text { (HCV-229E) }\end{array}$ & 6.0 to 8.0 & $\begin{array}{l}\text { Experiment conducted } \\
\text { in } 4,22,33 \text { and } 37^{\circ} \mathrm{C} .\end{array}$ & $\begin{array}{c}\mathrm{pH} \text { level between } 6.0 \text { to } 8.0 \text { is } \\
\text { ideal for coronavirus } 229 \mathrm{E} \text { to } \\
\text { grow. An acidic } \mathrm{pH} \text { below } 6.0 \\
\text { at } 37^{\circ} \mathrm{C} \text { show decrease in viral } \\
\text { infectivity. }\end{array}$ \\
\hline $\begin{array}{l}\text { Survival of severe acute } \\
\text { respiratory syndrome } \\
\text { coronavirus } \\
\text { Lai et al. [7] }\end{array}$ & Case Study & $\begin{array}{l}\text { Severe Respiratory } \\
\text { Coronavirus Type-1 } \\
\quad \text { (SARS-CoV) }\end{array}$ & $>9.0$ & Room Temperature & $\begin{array}{c}\text { Stool specimens injected } \\
\text { with SARS-CoV show higher } \\
\text { survival rate at pH level higher } \\
\text { than } 9 \text { when observed in room } \\
\text { temperature. }\end{array}$ \\
\hline $\begin{array}{c}\text { A pH-dependent switch } \\
\text { mediates conformational } \\
\text { masking of SARS-CoV-2 } \\
\text { spike } \\
\text { Zhou T. et al. [11] }\end{array}$ & Case study & $\begin{array}{l}\text { Severe Respiratory } \\
\text { Coronavirus Type-2 } \\
\text { (SARS-CoV-2) }\end{array}$ & $\begin{array}{l}5.5-6.0 \text { ideal for } \\
\text { viral entry; lower } \\
\text { than } 5.5 \text { can block } \\
\text { the process }\end{array}$ & Room Temperature & $\begin{array}{l}\text { pH } 5.5-6.0 \text { is favored by } \\
\text { SARS-CoV-2 spike protein } \\
\text { RBD to actively engage } \\
\text { with epithelial cell receptors. } \\
\text { Therefore, by altering pH level } \\
\text { or masking the "UP" RBD } \\
\text { conformation can potentially } \\
\text { block viral infection }\end{array}$ \\
\hline $\begin{array}{c}\text { The Potential of Coconut } \\
\text { Oil and its Derivatives as } \\
\text { Effective and Safe Antiviral } \\
\text { Agents Against the Novel } \\
\text { Coronavirus (nCoV-2019) } \\
\text { Dayrit F. et al.[12] }\end{array}$ & $\begin{array}{c}\text { Review article/Experiment } \\
\text { Suggestion }\end{array}$ & $\begin{array}{c}\text { Severe Respiratory } \\
\text { Coronavirus Type-2 } \\
\text { (SARS-CoV-2) }\end{array}$ & $\mathrm{N} / \mathrm{A}$ & Room Temperature & $\begin{array}{l}\text { The use of lauric acid from } \\
\text { coconut oil can potentially } \\
\text { block viral entry by balancing } \\
\text { the } \mathrm{pH} \text { level of an acidic body } \\
\text { that normally favors viral } \\
\text { infection. }\end{array}$ \\
\hline $\begin{array}{c}\text { The Infectious Bronchitis } \\
\text { Coronavirus Envelope Protein } \\
\text { Alters Golgi pH To Protect the } \\
\text { Spike Protein and Promote } \\
\text { the Release of Infectious } \\
\text { Virus } \\
\text { Westerbeck et al. [13] }\end{array}$ & Case Study & Coronaviruses (CoVs) & $\begin{array}{l}6.2 \sim 6.7 ;>6.7 \text { for } \\
\text { better survival of } \\
\text { virus }\end{array}$ & Room Temperature & $\begin{array}{l}\text { Infectious Bronchitis Virus } \\
\text { (IBV) can increases pH level in } \\
\text { the Golgi complex to preserve } \\
\text { the spike protein for viral } \\
\text { infection. Therefore, pH over } \\
6.7 \text { allow better success for } \\
\text { viral entry. }\end{array}$ \\
\hline
\end{tabular}

around 4.0 4.3 can prevent HIV infecting the human host [8]. They also mentioned a study carried out by the team in 2004 on the use of fresh lemon or lime juice ( $\mathrm{pH}=2.3$ and 2.4 respectively) at $20 \%$ concentration could inactivate viruses [10]. The protocol uses filtered pools of lemon juice ( $\mathrm{pH} 2.3$ ) and lime juice ( $\mathrm{pH}$ 2.4), which added to a selection of various culture medium of HIV-BaL viruses. They confirmed that $20 \%$ concentration of lime or lemon juice reduced the $\mathrm{pH}$ to $2.9,90 \%$ of the viruses are inactivated in $2 \mathrm{~min}$. When they observe the culture medium in a $10 \%$ concentration of lemon or lime juice ( $\mathrm{pH} 3.4-3.7$ ), only $50 \%$ of the viruses are inactivated in $2 \mathrm{~min}$ [10]. In further discussion, mentioned that a clinical trial on lemon juice or lime juice used for HIV treatment should be conducted ethically with an effective protocol to lower HIV spreading [8]. Furthermore, we can utilize these acidic fluids to test the activity of the novel Coronavirus (COVID-19) at a set range of temperatures (20 ${ }^{\circ} \mathrm{C} \sim 37^{\circ} \mathrm{C}$ ) and in a duration time exposure to observe the outcome. This proposed experiment may eventually help to solve a low quantity of PPEs and disinfectants available in certain countries.

Since plenty of the acidic liquid listed above are available with minimum or at least known side effect on the food surface. It would be great if the effect of dosage, time, and temperature can monitor the effect on inactive the COVID-19. The potential simple protocol could save many people from immunodeficiency because of malnutrition and save much food to serve as virus-free.

\section{References}

1. Davidson H (2020) Around $20 \%$ of global population under coronavirus lockdown. Coronavirus outbreak.

2. Maggini S, Pierre A, Calder PC (2018) Immune function and micronutrient requirements change over the life course. Nutrients 10: 15331.

3. Ashour HM, Elkhatib WF, Md Masudur R, Elshabrawy HA (2020) Insights into the recent 2019 novel coronavirus (SARS-CoV-2) in light of past human coronavirus outbreaks. Pathogens 9: 186.

4. Cascella M, Rajnik M, Cuomo A, Dulebohn SC, Di Napoli R (2020) Features, evaluation and treatment coronavirus (COVID-19). In StatPearls.

5. Lamarre A, Talbot PJ (1989) Effect of $\mathrm{pH}$ and temperature on the infectivity of human coronavirus 229E. Canadian journal of microbiology 35: 972-974.

6. Darnell ME, Subbarao K, Feinstone SM, Taylor DR (2004) Inactivation of the coronavirus that induces severe acute respiratory syndrome, SARS-CoV. J Virol Methods 121: 85-91.

7. Lai MY, Cheng PK, Lim WW (2005) Survival of severe acute respiratory syndrome coronavirus. Clinical Infectious Diseases 41: e67-e71.

8. Short RV (2006) New ways of preventing HIV infection: thinking simply, simply thinking. Philos Trans R Soc Lond B Biol Sci 361: 811-820.

9. (2020). Summary of the evaluation of pH data collected as of August 6, 2015

10. Short R, McCoombe SG, Maslin CLV, Crowe SM (2004) Lemon and lime juice as potent natural microbicides. In: AIDS 2004: Proceedings of the XV International AIDS Conference 2004. International Aids Society. International Aids Society.

11. Zhou T, Tsybovsky Y, Olia AS, Gorman J, Rapp MA, et al. (2020) A pHdependent switch mediates conformational masking of SARS-CoV-2 spike. bioRxiv.

12. Dayrit FM, Newport MT (2020) The Potential of Coconut Oil and its Derivatives 
as Effective and Safe Antiviral Agents Against the Novel Coronavirus (nCoV2019).

13. Westerbeck JW, Machamer CE (2019) The infectious bronchitis coronavirus envelope protein alters Golgi pH To protect the spike protein and promote the release of infectious virus. Journal of Virology.

14. Saghiri, M.A, Saghiri, A.M (2017) In memoriam: Dr. Hajar Afsar Lajevardi MD, MSc, MS (1955-2015). Iran J. Pediatr. 27 (1), e8093.

\section{Acknowledgement}

MAS is a recipient of New Jersey Health Foundation Innovation Award. This publication is dedicated to the memory of Dr. H. Afsar Lajevardi [14] a legendry pediatrician (1953-2015). The views expressed in this paper are those of the authors and do not necessarily reflect the views or policies of the affiliated organizations. The authors hereby announced that they have had active cooperation in this scientific study and preparation of the present manuscript. The authors confirm that they have no financial involvement with any commercial company or organization with direct financial interest regarding the materials used in this study. 